\title{
Social Construction Development of Sociology Laboratory for Learning High Order Thinking Skills
}

\author{
Atik Catur Budiati*, Ravik Karsidi, Nunuk Suryani, Muhammad Akhyar \\ Doctoral Program of Educational Science Department, Faculty of Education and Teacher Training, Sebelas Maret University, \\ Indonesia
}

Received December 9, 2019; Revised January 19, 2020; Accepted February 25, 2020

Copyright $\bigcirc 2020$ by authors, all rights reserved. Authors agree that this article remains permanently open access under the terms of the Creative Commons Attribution License 4.0 International License

\begin{abstract}
The existence of laboratories at schools aims to produce theoretical concepts through experimental activities in the instructional process. However, it tends to be dominated by natural science. On the one hand, one of the efforts to respond to the challenges of the 21st Century, students must acquire High Order Thinking Skills (HOTS) competencies included in sociology learning. This study aims to identify the social construction of the development of sociology laboratories as a strategy for developing HOTS learning. This study uses a qualitative descriptive approach by phenomenology. Data is obtained through interviews, analysis of learning tools documents including assessment systems, and literature studies. Interviews were conducted with sociology teachers and high school students majoring in social science. Data validity uses method triangulation by comparing interview data, document analysis and literature studies. Data analysis uses social construction theory. Based on research results, it shows that the development of sociology laboratories in learning can support the creation of HOTS competencies among high school students. This is because through simple research activities, students are able to think critically and provide alternative solutions to social problems that are used as research objects. In developing their thinking, students have imagination and can develop concepts of sociological abstraction that are originated from the research projects undertaken.
\end{abstract}

Keywords Social Construction, Sociology Laboratory, HOTS Learning

\section{Introduction}

The development of science and technology that has entered Revolution 4.0 encourages the development of competencies possessed by students who are not limited to cognitive competencies. According to Ball, Joyce, Anderson-Butcher (2016), that to increase success in the future, high school and college graduates must be equipped with academic skills, life skills and careers. Therefore, it is very important for schools to consider students' mastery of non-cognitive skills, especially since this field is an emerging priority in the global market as a form of educational reform. Furthermore, the results of research by Alibek, Sharipbay, Ulyukova, Sabyrov, and Kuzenbaye (2016) state that the rapid spread of technology can be utilized to assist learning activities in the 21 st Century. The era of globalization is driving the process of integrating technology and information in education so as to encourage the creation of quality learning to support the creation of High Order Thinking Skills (HOTS) competencies.

On the one hand, based on Messineo's results (2017), it states that it is necessary to consider learning strategies in sociology classes to improve student learning outcomes which include metacognition, sympathy, guided practice, multitasking and empathy. Therefore, learning in sociology class must be developed to support HOTS learning as an effort to answer the challenges of the 21st Century. According to Shilo and Ragonis (2017), educational policy makers have developed a curriculum that aims to help students develop higher-order thinking skills. However, the development of high-level thinking strategies depends on the teaching scenario carried out by the teacher. Alismail and McGuire (2015) recommend that curriculum connected with the real world can support students' participation, motivation, and knowledge of academic subjects and prepare students for future life.

According to $\mathrm{Li}$, Lou, Chu, and Liu (2009), it mentioned that learning through live and real projects can create a cooperative learning environment so that students can get problem solving knowledge and skills. Lake, Fernando, and Eardley (2016) recommend an effective pedagogical approach through laboratory design as a 
continuous educational innovation by involving the community and students in participatory research to overcome various social problems. This concept is in line with the objectives of the social laboratory developed by Hassan (2014) who states that the social laboratory is a platform created to overcome social problems.

This is in accordance with the orientation of sociology subjects that strive to increase individual and social awareness, having sensitivity and concern with various social problems (Syllabus Curriculum 2013 version 2016). Therefore, sociology teachers can create learning strategies through various experimental activities that are packaged by developing sociology laboratories in schools. As confirmed by Guggenheim (2012), the laboratory is an important metaphor for producing scientific knowledge in sociology. This condition is in line with efforts to develop high-level thinking skills competency among high school students. Furthermore, Klentien and Wannasade (2016) emphasize that learning models through virtual laboratories can improve analytical thinking skills and evaluate the ability to conduct science projects for secondary school students.

Based on the existing conditions, this paper aims to identify the social construction of the sociology laboratory development as a strategy for developing HOTS learning. Hopefully, the results of this study will be the first step in developing a sociology laboratory in high school for HOTS learning.

\section{Literature Review}

The existence of school laboratories was introduced by John Dewey in 1896, which aimed to study educational innovation through an experimental approach. This condition will give birth to the continuous development of human character in response to school needs (Mayhew \& Edwards, 1936). Through laboratory schools, John Dewey wants to create an interactive learning community to support students' social and intellectual competencies, including providing a space where theoretical ideas can be implemented and tested in learning (Jacobs, 2010).

Furthermore, Ka Yuk Chan C. (2012) explains that learning in the laboratory is learning that takes place in a space where students can observe, practice, and experiment with objects, materials, phenomena, and ideas both individually and in groups. This means that learning through the laboratory is not limited to physical space, but can also occur in various forms of space. According to Frias and Garcia (2017), social laboratories are places designed to conduct experiments to observe and analyze social phenomena and as a space to produce scientific innovations. Sociology is a subject included in the social sciences family.

In the Encyclopedia of Education Theory and Philosophy (2014), the development of John Dewey's school laboratories can be done through project activities provided by teachers and can contribute to the progressive progress of industrial society. When students are given challenging project assignments, students will get used to working so as to encourage cognitive and social growth. This is in line with the concept of the Zone Development Proximal (ZPD) developed by Vygostky (1978) that the distance between levels of development is determined through the ability to learn and solve problems with the help of adults or through collaboration with peers. Through project activities, students can improve their analytical thinking and evaluation skills (Klentien and Wannasade, 2016), which are the competencies of higher level thinking skills.

Ramadhan, S., Mardapi, D., Prasetyo, ZK, \& Utomo, HB (2019) states that higher-level thinking occurs when someone takes information and new information is stored in memory and is interrelated and extends this information to achieve goals or find answers in a dilemma situation. It was further stated that higher-order thinking skills were always associated with Bloom's taxonomic revision, especially the top three including analyzing (C4), evaluating (C5), and making (C6). Better (2013) explains learning sociology requires learning strategies that require active students. This is to provide a tool for students to see the world as a sociologist and be able to critically analyze inequalities that occur in society. The learning step that needs to be done is the provision of challenging projects where students collect data through their life experiences and analyze it as a sociologist.

\section{Methodology}

This study uses a qualitative descriptive approach to the type of phenomenology. According to Pathak (2017), a phenomenological research design is a study that emphasizes the importance of the perspective and interpretation of individuals about certain phenomena. In this case, the interpretation of teachers and students in understanding the development of sociology laboratories for HOTS learning is needed. Data collection is done by in-depth interviews and document analysis. Interviews were conducted with sociology teachers and high school students. The selection of informants based on purposive sampling is that the selected informants have characteristics in accordance with the objectives of the study. Characteristics of teacher informants include teaching more than 5 years, being certified, and developing project learning. While the characteristics of students are from social science majors and get project learning. Documents used in the study include learning tools consisting of lesson plans, teaching materials, and assessment systems. The data validity process uses a triangulation method that compares interview data with the results of the learning device document. The data 
analysis technique uses the interaction model of Miles and Hubberman (1992) with an approach to the analysis of social construction theory. According to Mendelshohn (1977), social construction is an attempt to understand reality that is built and forced socially but is consciously accepted by individuals in society. Depart from this understanding, this study seeks to identify the concept of developing a sociology laboratory for HOTS learning in accordance with what happened in sociology classes.

\section{Findings and Discussion}

Learning through the laboratory can be done with a variety of strategies such as observing a social problem or social phenomenon, conducting research directly in the community, or experimenting with the help of technology. In this case the sociology teacher develops project activities through simple research where students select the object of research and discuss with the teacher in the classroom. Project activities are usually carried out at the end of the semester after students have acquired all the sociological concepts that must be learned. Therefore, the general goal of developing learning through laboratories is to find abstract concepts into practical concepts based on facts that occur in society. With simple research, the teacher provides opportunities and access for students to develop abstract concepts of sociology that have been taught previously. For teachers, this result can determine the target indicators of achievement of competencies that have been developed in the lesson plan.

The main concern for sociology teachers is on designing lesson plans to support the implementation of project activities through simple research. The time needed for the implementation of this lesson is at least 2 meetings long so it needs careful preparation. The first meeting, the teacher explained the guidelines for the preparation of simple research activities starting from the selection of topics or research objects, the division of groups and the preparation of simple research proposals. The second meeting, students already have a draft research report based on data that has been found and the results discussed by the teacher. Then students and their groups make improvements to the report and submit it to the teacher. While the project implementation time is done outside of class hours, simple research is carried out in the market, government, public space, community including observing people's behavior. For this reason, the learning strategies developed must be known and understood by teachers and students can be explored through each teacher's lesson plan (See Table 1).

Table 1. Matrix of Lesson Plan Analysis

\begin{tabular}{|c|c|c|}
\hline No & Reviewed Aspects & Results of Reviewed Lesson Plan \\
\hline 1 & $\begin{array}{l}\text { Formulation of } \\
\text { Competency Achievement } \\
\text { Indicators }\end{array}$ & $\begin{array}{l}\text { 1. Arranged based on basic competencies } \\
\text { 2. Using operational verbs } \mathrm{C} 4, \mathrm{C} 5 \text {, or } \mathrm{C} 6 \text { (Bloom's taxonomy) } \\
\text { 3. Developing cognitive, affective and psychomotor competencies }\end{array}$ \\
\hline 2 & $\begin{array}{l}\text { Selection of Resources, } \\
\text { Media, and Learning } \\
\text { Methods }\end{array}$ & $\begin{array}{l}\text { 1. Adjusting the indicators of competency achievement } \\
\text { 2. Adjusting the characteristics of students } \\
\text { 3. Arrange the development of simple research guidelines clearly and can } \\
\text { be practiced by students }\end{array}$ \\
\hline 3 & Learning Scenarios & $\begin{array}{l}\text { 1. Display the introduction, core and closing activities clearly and clearly } \\
\text { 2. Learning steps with a scientific approach include observing, asking } \\
\text { questions, gathering information, associating information and } \\
\text { communicating it } \\
\text { 3. Adjusting to the learning method } \\
\text { 4. Organize activities systematically in the order of material } \\
\text { 5. Manage learning time effectively }\end{array}$ \\
\hline 4 & Authentic Research Design & $\begin{array}{l}\text { 1. Adjusting the indicators of competency achievement namely project } \\
\text { activities through simple research activities } \\
\text { 2. Arranging assessment instruments which includes } 3 \text { things namely } \\
\text { cognitive, affective and psychomotor }\end{array}$ \\
\hline
\end{tabular}

Source: Processed Data Results, 2019 \& Lesson Plan Study Instrument, 2016 
Table 2. Student Interpretation Matrix about Project Activities through Simple Research

\begin{tabular}{llll}
\hline No & Analyzed Aspects & & \multicolumn{1}{c}{ Results of Student Interpretation } \\
\hline 1 & Affective Competence & 1. Compile a report based on the data found \\
& & 2. Gather assignments in time \\
& 3. Be able to express their opinions critically \\
\hline 2 & Cognitive Competence & 1. Able to arrange abstract concepts into practical concepts \\
& 2. Develop critical and analytical thinking about the object of research \\
& 3. Mapping the concepts developed in simple research \\
\hline 3 & Psychomotor Competence & 1. Choose simple research topics according to indicators of competency \\
& & 2. Manage the time of data collection until the writing of the report \\
& 3. It is the original work of students with the help of teachers \\
\hline
\end{tabular}

Source: Processed Data Results, 2019

From the student's point of view, it is necessary to emphasize to the sociology teacher that the concept of sociology can be applied to see the socio-cultural phenomena that occur in society as a feature of sociology as an applied science. Students need to arrange a simple research implementation schedule so they can collect research reports on time. In addition, it can be used as a division of tasks as part of teamwork. Sociological concepts that are the object of research must be understood correctly so that there is no error of thought when collecting data. In addition, the competencies developed by sociology teachers are to build students' thinking including communication skills, interacting, writing reports, including the ability to obtain valid data. Through data collection activities critical thinking skills of students can be from and at the time of preparation of the report can be identified to overcome them (See Table 2).

Learning through the laboratory gives students the opportunity to develop their imagination that they did not have before. This is because the teacher facilitates students to learn the material, think critically and apply it to real situations, which can be done with the help of technology. Teachers can create creative learning where students are willing to think and learn, which requires group collaboration so as to further enhance the students' reasoning and critical abilities to achieve learning goals.

In the learning design the teacher can make the project theme, in this case simple research is in accordance with the material in the subject of sociology. The steps taken include defining the concept of sociology, mapping the information needed, finding a network of concepts with real situations, writing reports, and presenting simple research results to the teacher and classmates. Meanwhile, to determine the HOTS learning indicators the teacher conducts an assessment system through oral tests to assess individual competencies and research reports to assess group competencies. (See Figure 1). 


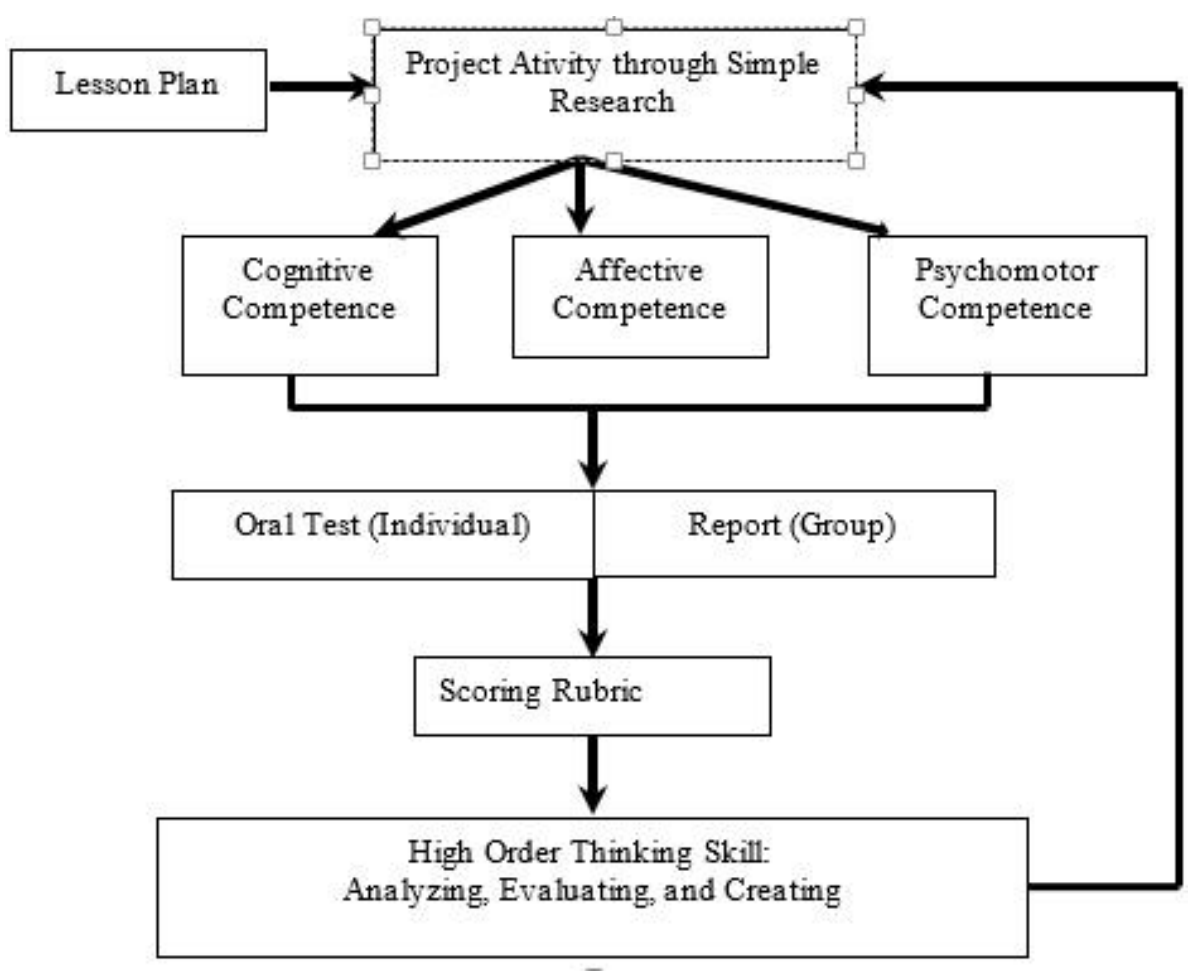

(Source: Data Processing, 2019).

Figure 1. Social Construction of Laboratory Development for HOTS Learning

\section{Conclusions}

To understand the concept of knowledge in sociology, teachers need to develop interactive learning strategies through assignments in the form of simple research. For sociology teachers, it is important to create practical sociology classes so students have challenges in dealing with social problems that occur in accordance with the objectives of learning sociology. The teacher needs to prepare a mature learning design because simple research activities require a minimum of two learning meetings. On the one hand, through simple research activities students can understand abstract and theoretical sociological concepts into concepts that are easily understood and applied. This condition creates critical and analytical thinking of students in understanding social phenomena that are the objects of sociology learning. Therefore, it can be concluded that teachers and students construct project-based learning through simple research in an effort to build students' competencies for critical thinking and problem solving.

\section{REFERENCES}

[1] Alismail, Halah Ahmed. McGuire, Patrick. (2015). 21st Century Standards and Curriculum: Current Research and Practice. Journal of Education and Practice, Vol. 6, No. 6, ISSN 2222-1735 (Paper) ISSN 2222-288X (Online)
[2] Ball, Annahita; Joyce, Hillary D.; and Anderson-Butcher, Dawn. (2016) Exploring 21st Century Skills and Learning Environments for Middle School Youth. International Journal of School Social Work: Vol. 1: Iss. 1. https://doi.org/10.4148/2161-4148.1012

[3] Better, Alison. (2013). Learning from Experience: Integrating Students' Everyday Lives into the Urban Community College Sociology Classroom. Published online: 4 December 2013. Springer Science+Business Media New York. pp 385-395. DOI 10.1007/s12108-013-9192-7

[4] Daher, W., Tabaja-Kidan, A., \& Gierdien, F. (2017). Educating Grade 6 Students for Higher-Order Thinking and tts Influence On Creativity. Pythagoras, 38 (1), a350. https://doi.org/10.4102/ pythagoras. v38i1.350

[5] Daher, W., Tabaja-Kidan, A., \& Gierdien, F. (2017). Educating Grade 6 Students for Higher-Order Thinking and tts Influence On Creativity. Pythagoras, 38 (1), a350. https://doi.org/10.4102/ pythagoras. v38i1.350

[6] Frias, Esteban Romero. Garcia, Nicolas Robinson. (2017). Social Labs in Universities: Innovation and Impact in Medialab UGR. Comunicar, n. 51, v. XXV, 2017 | Media Education Research Journal | ISSN: 1134-3478; e-ISSN: 1988-3293

[7] Guggenheim, Michael. (2012). Laboratizing and de-Laboratizing the World: Changing Sociological Concepts for Places of Knowledge Production. History of the Human Sciences 25 (1), pp. 99-118. sagepub.co.uk/journalsPermissions.nav. DOI: 10.1177/0952695111422978

[8] Hassan, Zaid. (2014). The Social Labs Revolution: A New 
Approach to Solving Our Most Complex Challenges. San Francisco: Berrett-Kohler Publishing.

[9] Jacobs, B. (2010). Dewey Laboratory School. In C. Kridel (Ed.), Encyclopedia of curriculum studies. (pp. 291-293). Thousand Oaks, CA: SAGE Publications, Inc.doi: http://dx.doi.org/10.4135/9781412958806.n161

[10] Ka Yuk Chan C. (2012) Laboratory Learning. In: Seel N.M. (eds) Encyclopedia of the Sciences of Learning. Springer, Boston, MA

[11] Klentien, Unchan. Wannasade, Wannachai. 2016. Development of Blended Learning Model with Virtual Science Laboratory for Secondari Students. Procedia Social and Behavioral Sciences 217 pp $706-711$

[12] Lake, Danielle. Fernando, Hannah. Eardley, Dana. (2016). The Social Lab Classroom: Wrestling with-and Learning from-Suistainability Challenges. Suistainability: Science, Practice and Policy, 12:1, 76-78, DOI:10.1080/15487733.2016.11908155

[13] Lou, S. J., Chung, C. C., Dzan, W. Y., \& Shih, R. C. (2012). Construction of a Creative Instructional Design Model Using Blended, Project-Based Learning for College Students. Creative Education, 3(7), 1281-1290.

[14] Mayhew, Katherine Camp. Edwards, Anna Camp. (1936). The Dewey School: The Laboratory School of the University of Chicago 1896-1903. Appleton-Century Company in Corporate. New York London

[15] Mendelsohn, Everett. (1977). The Social Construction of Scientific Knowledge. In Everett Mendelsohn, Peter Weingart, \& Richard Whitley D (Eds.), The Social Production of Scientific Knowledge. Dordrecht, Holland. ISBN-13: 978-90-277-0776-5. e-ISBN-13: 978-94-010-1186-0. DO1: 10.1007/978-94-010-1186-0

[16] Messineo, Melinda. (2017). Using The Science of Learning to Improve Student Learning in Sociology Classes. Teaching Sociologi, 1-11

[17] Miles, B. Mathew \& Huberman, Michael. (1992). Analisis Data Kualitatif. Jakarta. Universitas Indonesia

[18] Pathak, Vinay Chandra. (2017). Phenomenological Researh: A Study of Lived Experiences. Volume 3 Issue 1, IJARIIE. ISSN (O) -2395-4396. www.ijariie.com

[19] Ramadhan, S., Mardapi, D., Prasetyo, Z. K., \& Utomo, H. B. (2019). The development of an instrument to measure the higher order thinking skill in physics. European Journal of Educational Research, 8(3), 743-751.https://doi.org/10.12973/eu-jer.8.3.743

[20] Shilo, Gila. \& Ragonis, Noa. (2017): A New Approach to High-Order Cognitive Skills in Linguistics: Problem-Solving Inference in Similarity to Computer Science, Journal of Further and Higher Education, DOI:10.1080/0309877X.2017.1361515

[21] Vygotsky, L. (1978). Mind in Society: The Development of Higher Psychological Processes. Cambridge, MA: Harvard University Press 